\title{
A New Approach to Clinical Care of Juvenile Idiopathic Arthritis: The Juvenile Arthritis Multidimensional Assessment Report
}

\author{
GIOVANNI FILOCAMO, ALESSANDRO CONSOLARO, BENEDETTA SCHIAPPAPIETRA, SARA DALPRÀ, \\ BIANCA LATTANZI, SILVIA MAGNI-MANZONI, NICOLINO RUPERTO, ANGELA PISTORIO, SILVIA PEDERZOLI, \\ ADELE CIVINO, DINARA GUSEINOVA, ESTER MASALA, STEFANIA VIOLA, ALBERTO MARTINI, \\ and ANGELO RAVELLI
}

ABSTRACT. Objective. To develop and test a new multidimensional questionnaire for assessment of children with juvenile idiopathic arthritis (JIA) in standard clinical care.

Methods. The Juvenile Arthritis Multidimensional Assessment Report (JAMAR) includes 15 parent or patient-centered measures or items that assess well-being, pain, functional status, health-related quality of life, morning stiffness, disease activity, disease status and course, joint disease, extraarticular symptoms, side effects of medications, therapeutic compliance, and satisfaction with illness outcome. The JAMAR is proposed for use as both a proxy-report and a patient self-report, with the suggested age range of 7-18 years for use as a self-report. From March 2007 to September 2009, the questionnaire was completed by the parents of 618 children with JIA in 1814 visits and by 332 children in 749 visits.

Results. The JAMAR was found to be feasible and to possess face and content validity. All parents and children reported that the questionnaire was simple and easy to understand. Completion and scoring appeared to be quick, requiring $<15$ minutes. There were very few missing data. Parents' proxy-reported and children's self-reported data were remarkably concordant. The JAMAR provided thorough information for the study patients about recent medical history and current health status. It performed similarly across different children's ages and characterized the level of disease activity and disability well.

Conclusion. The development of the JAMAR introduces a new approach in pediatric rheumatology practice. This new questionnaire may help enhance the quality of care of children with JIA (First Release March 1 2011; J Rheumatol 2011;38:938-53; doi:10.3899/jrheum.100930)

Key Indexing Terms:

JUVENILE IDIOPATHIC ARTHRITIS OUTCOME RESEARCH PATIENT PERSPECTIVE

From the Istituto di Ricovero e Cura a Carattere Scientifico G. Gaslini, Genova; Istituto di Ricovero e Cura a Carattere Scientifico Fondazione Policlinico S. Matteo, Pavia; Azienda Ospedaliera Card. G. Panico, Tricase; and the Università degli Studi di Genova, Genova, Italy. G. Filocamo, MD, PhD, Dirgente Medico; A. Consolaro, MD, Research Fellow; B. Schiappapietra, MD, Resident in Pediatrics; S. Dalprà, MD; B. Lattanzi, MD, Istituto di Ricovero e Cura a Carattere Scientifico G. Gaslini; S. Magni-Manzoni, MD, Dirgente Medico, Istituto di Ricovero e Cura a Carattere Scientifico Fondazione Policlinico S. Matteo N. Ruperto, MD, MPH, Dirgente Medico; A. Pistorio, MD, PhD, Dirgente Medico; S. Pederzoli, MD, Resident in Pediatrics, Istituto di Ricovero e Cura a Carattere Scientifico G. Gaslini; A. Civino, MD, Dirigente Medico, Azienda Ospedaliera Card. G. Panico; D. Guseinova, MD, Research Fellow; E. Masala, MD, Resident in Pediatrics; S. Viola, MD, Dirgente Medico, Istituto di Ricovero e Cura a Carattere Scientifico G. Gaslini; A. Martini, MD, Professor of Pediatrics; A. Ravelli, MD, Associate Professor of Pediatrics, Istituto di Ricovero e Cura a Carattere Scientifico G. Gaslini, Università degli Studi di Genova.

Address correspondence to Dr. A. Ravelli, Pediatria II, Istituto

G. Gaslini, Largo G. Gaslini 5, 16147 Genova, Italy.

E-mail:angeloravelli@ospedale-gaslini.ge.it

Accepted for publication November 15, 2010.
In recent years, there has been an increasing interest in parent/patient-reported outcomes (PRO) in juvenile idiopathic arthritis (JIA) $)^{1,2,3,4,5}$. Incorporation of these measures in patient assessment is deemed important as they reflect the parents' and children's perception of the disease course and effectiveness of therapeutic interventions. Because the physician's evaluation of the disease status drives therapeutic decisions, and these decisions are of foremost importance to parents and patients, integration of their perspective in clinical evaluation may facilitate concordance with physician's choices and compliance with therapeutic prescriptions $6,7,8$. Thus, information obtained from the parent or the child may contribute significantly to medical decision-making and to the success of patient care.

A number of measures for the assessment of PRO in children with JIA have been developed over the years, including visual analog scales (VAS) for rating of child's overall 
well-being and intensity of pain, and questionnaires for the evaluation of functional ability and health-related quality of life (HRQOL) 9,10,11,12,13,14,15,16,17,18,19,20. However, other PRO not addressed by conventional instruments, such as evaluation of morning stiffness and overall level of disease activity, rating of disease status and course, proxy- or self-assessment of joint involvement and extraarticular symptoms, description of side effects of medications, and assessment of therapeutic compliance and satisfaction with the outcome of the illness, may provide valuable insights into the influence of the disease and its treatment. Currently, a clinical intrument that groups all PRO used in the assessment of children with JIA does not exist. Such a tool would provide a physician with a thorough and systematic overview of the patient status to be scanned briefly at the start of the visit. This would facilitate focus on matters that require attention, leading to more efficient and effective clinical care.

These considerations led us to develop a multidimensional questionnaire for the assessment of children with JIA in standard clinical care that incorporates all main PRO. We describe this new instrument, the Juvenile Arthritis Multidimensional Assessment Report (JAMAR), and report the results to date with its use in our patient population.

\section{MATERIALS AND METHODS}

Development of the JAMAR. The JAMAR was devised by a group of 7 pediatric rheumatologists (GF, AC, SMM, NR, SV, AM, AR), based on their experience ( 3 to $>20$ years) in clinical assessment of children with JIA, and on a literature review on PRO in adult and pediatric patients with chronic arthritis ${ }^{9}, 10,11,12,13,14,15,16,17,18,19,20,21,22,23,24$. To make the JAMAR feasible and practical, it was decided that all measures included in the instrument should be short and easy to complete and score. A total of 32 measures were considered for inclusion in the instrument. After extensive discussion of the relative importance and suitability of each measure, a measure was retained only when there was agreement of at least $6 / 7$ members of the panel that it should be kept in the questionnaire. Thus, content validity was obtained by the members of the panel. The following 15 measures/items were included: (1) Assessment of functional ability, through the Juvenile Arthritis Functionality Scale (JAFS) ${ }^{15}$. Briefly, the JAFS is a 15 -item questionnaire in which the ability of the child to perform each task is scored as follows: 0 = without difficulty, 1 = with difficulty, $2=$ unable to do. The total score ranges from 0 to 30 . (2) Rating of the intensity of child's pain on a 21 -numbered circle VAS $(0=$ no pain; $10=$ very severe pain $)^{25}$. (3) Assessment of HRQOL, through the Pediatric Rheumatology Quality of Life Scale (PRQL) ${ }^{20}$. Briefly, the PRQL is a 10 -item questionnaire that includes 2 subdimensions, physical health $(\mathrm{PhH})$ and psychosocial health $(\mathrm{PsH})$, each composed of 5 items. The responses are "never" (score $=0)$, "sometimes" (score $=1)$, "most of the time" (score $=2)$, and "all the time" ( score $=3$ ). The total score ranges from 0 to 30 , higher scores indicating worse HRQOL. A separate score for the $\mathrm{PhH}$ and $\mathrm{PsH}$ subscales (range 0-15) can be calculated. (4) Rating of child's overall well-being on a 21 -numbered circle VAS $(0=\text { very well; } 10=\text { very poorly })^{25}$. (5) Assessment of the presence of pain or swelling in the following joints or joint groups: cervical spine, lumbo-sacral spine, shoulders, elbows, wrists, small hand joints, hips, knees, ankles, and small foot joints. (6) Assessment of morning stiffness. (7) Assessment of extraarticular symptoms (fever and rash). (8) Rating of the level of disease activity on a 21-numbered circle VAS $(0=\text { no activity; } 10=\text { maximum activity })^{25}$. Although the ability of parents/patients to understand the meaning and to be able to report the extent of disease activity may be questionable, we decided to include this VAS to investigate whether it could be a better indicator of the level of disease activity than the well-being VAS. The latter scale has been found to reflect the effects of both disease process and damage, particularly in patients with long-lasting disease $\mathrm{e}^{26}$. (9) Rating of disease status at the time of the visit as remission; continued activity; or relapse. (10) Rating of disease course from previous visit as much improved; slightly improved; stable; slightly worsened; or much worsened. (11) Listing of medications the child is taking. (12) Description of side effects of medications. (13) Report of difficulties with medication administration. (14) Report of school problems caused by the disease. (15) A question about satisfaction with the outcome of the illness. Measures 1-6, 8, 9, 10, and 15 had been formally validated or tested in previous studies $15,20,25,27,28$. Items 7 and 11-14 were not meant to attain validation as they were only descriptive in nature.

To ensure face validity, the draft questionnaire was shown to 12 physicians ( 8 pediatric rheumatologists and 4 residents in pediatrics), 4 physiotherapists, and 3 specialist nurses who were not part of the JAMAR group, and to 1 clinical psychologist, and their opinion on the suitability of the instrument was queried. Although all agreed on the questionnaire, several points were raised regarding definition of items, which were discussed and partially incorporated in the final version. Face and content validity were tested further by asking a convenience sample of 49 children with JIA and their parents to complete the draft questionnaire and to criticize or comment about the design, content, structure, and response scale. Based on parents' and children's input, wording of questions regarding assessment of disease activity and therapeutic compliance, definitions of continued activity and disease flare, and some medication side effects was changed. Further, drawings of happy and sad faces were placed at the 2 ends of the VAS because some parents or, less frequently, children misinterpreted the score rule, particularly regardng the assessment of overall well-being, considering the score 10 as the best and the score 0 as the worst. After these tests, the questionnaire was refined further to reach its final version.

The English translation of Italian versions of the parent proxy-report of the JAMAR for ages 2-18 years and the child self-report for ages 7-18 are presented as Appendixes 1 and 2, respectively.

Patient selection and completion of the JAMAR. A parent or legal guardian of each patient seen at the study units from March 2007 to December 2009 who was $\leq 18$ years and was diagnosed with JIA by the International League of Associations for Rheumatology (ILAR) criteria ${ }^{29}$ was asked to complete the Italian parent-version of the JAMAR at each visit. At the same visits, the child (if aged more than 7 or 8 years) was asked to independently complete the Italian patient-version of the JAMAR. A researcher assisted parents and children if they had questions during questionnaire completion. However, no questionnaire was administered in the form of an interview. All parents/guardians provided written informed consent to participate in the study. The study was approved by the Institutional Review Board of the Istituto G. Gaslini, Genoa, Italy.

Additional clinical assessments. The following data were recorded for each patient: sex, onset age, ILAR category, and disease duration. At each visit, the attending physician rated the overall disease activity on a 21-numbered circle VAS $(0=\text { no activity; } 10=\text { maximum activity })^{25}$ and assessed the count of joints with swelling, tenderness/pain on motion, restricted motion, and active disease ${ }^{30}$. Acute-phase reactants included erythrocyte sedimentation rate and $\mathrm{C}$-reactive protein.

Statistics. Descriptive statistics were reported as medians and interquartile ranges for continuous variables and as absolute frequencies and percentages for categorical variables. Comparison of quantitative data between patient groups was by Mann-Whitney $U$ test in case of comparison of 2 groups and the nonparametric analysis of variance (Kruskal-Wallis test) in comparisons of 3 groups. Comparison of categorical variables between patient groups was by chi-square test or Fisher exact test, as appropriate, in cases of categorical variables. Correlations of quantitative measures included in the JAMAR between questionnaires completed by parents and children were assessed by Spearman's rank correlation test. All statistical tests

Personal non-commercial use only. The Journal of Rheumatology Copyright $@$ 2011 . All rights reserved. 
were 2-sided; a p value $<0.05$ was considered statistically significant. The statistical packages used were Statistica (StatSoft Corp., Tulsa, OK, USA) and Stata release 7 (Stata Corp., College Station, TX, USA).

\section{RESULTS}

Patient characteristics and questionnaire completion. A total of 618 children with JIA were included in the study. The demographic and clinical features as well as the values of physician-centered measures and acute-phase reactants of the 618 patients at study entry are presented in Table 1. A parent of each patient completed the JAMAR in a total of 1814 visits. In 749 of these visits, the JAMAR was also completed independently by 332 patients aged $\geq 7$ years. All parents and children reported that the JAMAR was simple and easy to understand, with only a few parents and children having questions. Frequent questions regarded the meaning of the word "block" in the HRQOL tool and the way to rate the VAS of disease activity. A random sample of parents and children were asked whether the JAMAR was simple and easy to understand in front of the researchers, and none reported that the questionnaire was too complex or difficult to understand. Completion of the questionnaire appeared to be quick. The mean time for 23 parents and 14 children (aged 8-16 yrs) to complete the questionnaire was $7.2 \mathrm{~min}$ utes (range 2.3-11.1) and 8.3 minutes (range 5-13.2), respectively. Scoring of the various components of the JAMAR by a health professional took less than 5 minutes.

Table 1. Main demographic and clinical features, physician-centered measures, and acute-phase reactants of the 618 study patients at study entry. Values are n (\%), unless indicated otherwise.

\begin{tabular}{|c|c|c|}
\hline Characteristic & $\mathrm{N}$ & \\
\hline Male & 618 & 129 (20.9) \\
\hline Female & 618 & $489(79.1)$ \\
\hline ILAR category & 618 & \\
\hline Systemic arthritis & & $46(7.4)$ \\
\hline Oligoarthritis persistent & & $267(43.2)$ \\
\hline Oligoarthritis extended & & $96(15.5)$ \\
\hline Polyarthritis rheumatoid factor-negative & & $138(22.3)$ \\
\hline Polyarthritis rheumatoid factor-positive & & $9(1.5)$ \\
\hline Psoriatic arthritis & & $15(2.4)$ \\
\hline Enthesitis-related arthritis & & $13(2.1)$ \\
\hline Undifferentiated arthritis & & $25(4.0)$ \\
\hline Median (IQR) age at disease onset, yrs & 618 & $2.9(1.8 ; 5.9)$ \\
\hline Median (IQR) age at visit, yrs & 618 & $8.8(4.8 ; 12.9)$ \\
\hline Median (IQR) disease duration, yrs & 618 & $3.7(1.2 ; 7.5)$ \\
\hline Median (IQR) physician's global assessment* & 503 & $1.0(0.0 ; 5.0)$ \\
\hline Median (IQR) no. active joints & 503 & $1(0 ; 3)$ \\
\hline Median (IQR) no. swollen joints & 503 & $1(0 ; 2)$ \\
\hline Median (IQR) no. tender joints & 503 & $1(0 ; 2)$ \\
\hline Median (IQR) no. restricted joints & 503 & $1(0 ; 2)$ \\
\hline Median (IQR) erythrocyte sedimentation rate** & 409 & $16(10.0 ; 27.8)$ \\
\hline Median (IQR) C-reactive protein*** & 419 & $0.3(0.3 ; 0.6)$ \\
\hline
\end{tabular}

* On a $0-10$ scale $(0=$ best; $10=$ worst $) ; * *$ normal $<20 \mathrm{~mm} / \mathrm{h}$; *** normal $<0.3 \mathrm{mg} / \mathrm{dl}$. ILAR: International League of Associations for Rheumatology; IQR: interquartile range.
There were very few missing data in parent- and child-reported questionnaires (Table 2). The center that collected the large majority of the questionnaires (the Istituto G. Gaslini, Genova) is a large tertiary care pediatric rheumatology center, whose catchment area extends to the entire country. The study sample is, therefore, likely representative of the whole spectrum of the educational and cultural background of the Italian children with JIA and their parents. No specific training was provided to questionnaire completers, either children or parents. They were instructed only on the general scope and composition of the questionnaire at the time of first completion.

Analysis of questionnaire data. Tables 3, 4, and 5 show results from the 618 questionnaires completed by parents at study entry (left column), and the results obtained at the time of first paired questionnaire completion by 332 children and parents (central and right columns). On average, patients had a low level of physical disability, with a median JAFS score of 0 . The physical and psychosocial domains of HRQOL were involved with equal frequency, although, on average, $\mathrm{PhH}$ scores were higher (worse) than PsH scores. Only around one-third of patients had a well-being VAS score of 0 , but a greater proportion $(42.8 \%$ ) had a pain VAS of 0 . Morning stiffness was recorded in $38.3 \%$ of patients and $58.9 \%$ of patients were reported to have swelling or pain in 1 or more joints. The joints most frequently affected were the knees, followed by the ankles, fingers, wrists, toes, and elbows. The patient's status at the time of the visit was judged as remission, persistent activity, or disease flare in $44.3 \%, 30.6 \%$, and $25.1 \%$ of instances, respectively. At the second visit, $48.4 \%$ of parents rated the disease course from initial visit as improved (much or slightly), 33.4\% as stable, and $18.2 \%$ as worsened (slightly or much).

It was found that $59.7 \%$ of patients were receiving medications at the time of the visit: $33.0 \%$ were taking methotrexate, $30.4 \%$ nonsteroidal antiinflammatory drugs (NSAID), and $11.3 \%$ biologics (most frequently etanercept). Side effects of medications were noted in $27.5 \%$ of patients. The most common adverse event was nausea, followed by gastrointestinal discomfort, mood changes, and headache. Problems with therapeutic compliance were uncommon (3.9\%). It was found that $30.5 \%$ of parents reported that the disease or its treatment caused difficulties at school; $65.9 \%$ of parents were satisfied with the outcome of the illness.

Comparison of parent proxy-reported and child self-reported data in paired questionnaires revealed a striking similarity for most items. The only significant difference concerned hypertrichosis as a side effect of medication, which was noted more commonly by parents.

To investigate whether child's age affected the reliability of completion of the questionnaire, we stratified children into 3 age groups $(<10,10-15,>15$ years $)$ and compared the parent-child Spearman correlations of quantitative measures included in the JAMAR across age groups. Overall,

Personal non-commercial use only. The Journal of Rheumatology Copyright (C) 2011. All rights reserved. 
Table 2. Frequency of missing data in parent and child-reported questionnaires. Values are $\mathrm{n}(\%)$.

\begin{tabular}{lccccc}
\hline & & \multicolumn{3}{c}{ Child Questionnaires } \\
Feature & $\begin{array}{c}\text { Parent-Only Questionnaires, Total, } \\
\mathrm{n}=618\end{array}$ & $\mathrm{n}=332$ & $\begin{array}{c}<10 \text { yrs, } \\
\mathrm{n}=92\end{array}$ & $\begin{array}{c}10-15 \text { yrs, } \\
\mathrm{n}=159\end{array}$ & $\begin{array}{c}> \\
\mathrm{n}=81\end{array}$ \\
\hline JAFS total score & $2(0.3)$ & $2(0.6)$ & $1(1.1)$ & $0(-)$ & $1(1.2)$ \\
PRQL total score & $38(6.1)$ & $2(0.6)$ & $1(1.1)$ & $1(0.6)$ & $0(-)$ \\
PRQL PhH score & $35(5.7)$ & $1(0.3)$ & $1(1.1)$ & $0(-)$ & $0(-)$ \\
PRQL PsH score & $38(6.1)$ & $2(0.6)$ & $1(1.1)$ & $1(0.6)$ & $0(-)$ \\
VAS well-being & $17(2.8)$ & $4(1.2)$ & $2(2.2)$ & $2(1.3)$ & $0(-)$ \\
VAS pain & $25(4.0)$ & $6(1.8)$ & $4(4.3)$ & $2(1.3)$ & $0(-)$ \\
VAS disease activity & $28(4.5)$ & $14(4.2)$ & $5(5.4)$ & $6(3.8)$ & $3(3.7)$ \\
Disease course & $34(5.5)$ & $13(3.9)$ & $5(5.4)$ & $6(3.8)$ & $2(2.5)$ \\
Morning stiffness & $12(1.9)$ & $5(1.5)$ & $4(4.3)$ & $1(0.6)$ & $0(-)$ \\
Disease status & $17(2.8)$ & $11(3.3)$ & $4(4.3)$ & $4(2.5)$ & $3(3.7)$ \\
Satisfaction with illness outcome & $34(5.5)$ & $7(2.1)$ & $4(4.3)$ & $3(1.9)$ & $0(-)$ \\
\hline
\end{tabular}

JAFS: Juvenile Arthritis Functionality Scale; PRQL: Pediatric Rheumatology Quality of Life scale; PhH: physical health; PsH: psychosocial health; VAS: visual analog scale.

Table 3. Assessment of functional ability, health-related quality of life, overall well-being, pain, and disease activity in the whole questionnaires completed by the parents at study entry and in the first questionnaire completed simultaneously by parents and children. Except where indicated, values are $\mathrm{n}(\%)$.

\begin{tabular}{|c|c|c|c|c|c|c|}
\hline \multirow[b]{3}{*}{ Feature } & \multicolumn{2}{|c|}{$\begin{array}{c}\text { Parent-Only } \\
\text { Questionnaires, } \mathrm{n}=618\end{array}$} & \multicolumn{4}{|c|}{$\begin{array}{c}\text { Paired Child-Parent } \\
\text { Questionnaires, } \mathrm{n}=332\end{array}$} \\
\hline & & & \multicolumn{2}{|c|}{ Children } & \multirow{2}{*}{\multicolumn{2}{|c|}{ Parents }} \\
\hline & $\mathrm{N}$ & & $\mathrm{N}$ & & & \\
\hline Median (IQR) JAFS total score* & 610 & $0(0 ; 3)$ & 330 & $0(0 ; 2)$ & 327 & $0(0 ; 2)$ \\
\hline Patients with JAFS total score $=0$ & 610 & $330(54.1)$ & 330 & $189(57.3)$ & 327 & $198(60.6)$ \\
\hline JAFS-LL score $=0$ & 613 & $377(61.4)$ & 330 & $210(63.6)$ & 330 & $222(67.3)$ \\
\hline JAFS-HW score $=0$ & 616 & $518(84.1)$ & 331 & $288(87.0)$ & 331 & $292(88.2)$ \\
\hline JAFS-US score $=0$ & 614 & $512(83.5)$ & 331 & $274(82.8)$ & 330 & $280(84.8)$ \\
\hline Median (IQR) PRQL total score* & 580 & $3(1 ; 6)$ & 330 & $3(1 ; 5)$ & 332 & $3(1 ; 6)$ \\
\hline Median (IQR) PRQL-PhH score** & 583 & $2(0 ; 4)$ & 331 & $1(0 ; 3)$ & 332 & $1(0 ; 3)$ \\
\hline Median (IQR) PRQL-PsH score** & 580 & $1(0 ; 3)$ & 330 & $1(0 ; 2)$ & 332 & $1(0 ; 3)$ \\
\hline Patients with PRQL total score $=0$ & 580 & $122(21.0)$ & 330 & $67(20.3)$ & 332 & $70(21.1)$ \\
\hline PRQL-PhH score = 0 & 583 & $190(32.6)$ & 331 & $113(34.1)$ & 332 & $118(35.5)$ \\
\hline PRQL-PsH score $=0$ & 580 & $216(37.2)$ & 330 & $118(35.8)$ & 332 & $121(36.4)$ \\
\hline Median (IQR) well-being score*** & 601 & $1.5(0.0 ; 5.0)$ & 328 & $0.5(0.0 ; 3.0)$ & 326 & $1.0(0.0 ; 4.0)$ \\
\hline Patients with well-being score $=0$ & 601 & $185(30.8)$ & 326 & $123(37.5)$ & 326 & $118(36.2)$ \\
\hline Median (IQR) pain score*** & 593 & $1.0(0.0 ; 4.0)$ & 318 & $0.5(0.0,3.0)$ & 319 & $0.5(0.0 ; 3.0)$ \\
\hline Patients with pain score $=0$ & 593 & $254(42.8)$ & 328 & $159(48.8)$ & 326 & $156(47.9)$ \\
\hline Median (IQR) disease activity score $* * *$ & * 590 & $1.0(0.0 ; 5.0)$ & 326 & $0.5(0.0 ; 3.0)$ & 326 & $0.5(0.0 ; 3.5)$ \\
\hline Patients with disease activity score $=0$ & 590 & $196(33.2)$ & 318 & $128(40.3)$ & 319 & $125(39.2)$ \\
\hline
\end{tabular}

* On a $0-30$ scale $(0=$ best; $30=$ worst $) ; * 0-15$ scale $(0=$ best; $15=$ worst $) ; * * 0-10$ scale $(0=$ best; $10=$ worst). IQR: interquartile range; JAFS: Juvenile Arthritis Functionality Scale; LL: lower limb; HW: hand-wrist; US: upper segment; PRQL: Pediatric Rheumatology Quality of Life scale; PhH: physical health; PsH: psychosocial health.

correlations were comparable, with the exceptions of a lower correlation of functional ability assessment in the younger age group and of psychosocial HRQOL assessment in the older age group (Table 6).

To evaluate whether the level of disease activity or disability affected the performance of the JAMAR, we stratified patients in 3 groups based on the number of active joints and the number of restricted joints. We then compared the values of quantitative and categorical measures included in the JAMAR across groups. As expected, the scores of functional ability and HRQOL tools and VAS scales increased (worsened) in parallel with the increase of the number of affected joints. Also as expected, the frequency of remission was lower, and the frequency of continued activity and disease flare higher, in patients with a higher number of affected joints (Table 7). These findings show that the JAMAR components characterize well the differences in level of disease activity and severity.

$$
\text { Personal non-commercial use only. The Journal of Rheumatology Copyright @ } 2011 \text {. All rights reserved. }
$$


Table 4. Assessment of morning stiffness, joint involvement, disease course from previous visit, disease status, and satisfaction with illness outcome in the questionnaire completed by the parents at study entry and in the first questionnaire completed simultaneously by parents and children. Values are $\mathrm{n}(\%)$.

\begin{tabular}{lcccccc}
\hline & \multicolumn{3}{c}{$\begin{array}{c}\text { Parent-Only } \\
\text { Questionnaires, } \mathrm{n}=618\end{array}$} & \multicolumn{3}{c}{$\begin{array}{c}\text { Paired Child-Parent } \\
\text { Questionnaires, } \mathrm{n}=332\end{array}$} \\
& & & & & Children & Parents \\
& $\mathrm{N}$ & & $\mathrm{N}$ & & $\mathrm{N}$ & \\
\hline Patients with morning stiffness & 606 & $232(38.3)$ & 327 & $100(30.6)$ & 327 & $97(29.7)$ \\
Patients with involvement of $\geq 1$ joint & 618 & $364(58.9)$ & 332 & $164(49.4)$ & 332 & $169(50.9)$ \\
Shoulder & 618 & $15(2.4)$ & 332 & $12(3.6)$ & 332 & $8(2.4)$ \\
Elbow & 618 & $39(6.3)$ & 332 & $15(4.5)$ & 332 & $21(6.3)$ \\
Wrist & 618 & $82(13.3)$ & 332 & $38(11.4)$ & 332 & $38(11.4)$ \\
Fingers & 618 & $104(16.8)$ & 332 & $38(11.4)$ & 332 & $39(11.7)$ \\
Hip & 618 & $20(3.2)$ & 332 & $13(3.9)$ & 332 & $13(3.9)$ \\
Knee & 618 & $210(34.0)$ & 332 & $86(25.9)$ & 332 & $90(27.1)$ \\
Ankle & 618 & $151(24.4)$ & 332 & $62(18.7)$ & 332 & $65(19.6)$ \\
Toes & 618 & $49(7.9)$ & 332 & $16(4.8)$ & 332 & $19(5.7)$ \\
Cervical spine & 618 & $22(3.6)$ & 332 & $15(4.5)$ & 332 & $16(4.8)$ \\
Lumbar spine & 618 & $7(1.1)$ & 332 & $2(0.6)$ & 332 & $3(0.9)$ \\
Patients judged in remission & 601 & $266(44.3)$ & 321 & $180(56.1)$ & 324 & $168(52.3)$ \\
In persistent activity & 601 & $184(30.6)$ & 321 & $71(22.1)$ & 324 & $72(22.4)$ \\
In disease flare & 601 & $151(25.1)$ & 321 & $70(21.8)$ & 324 & $84(26.2)$ \\
As much improved* & 401 & $144(35.9)$ & 160 & $74(46.3)$ & 166 & $64(38.6)$ \\
As slightly improved* & 401 & $50(12.5)$ & 160 & $22(13.8)$ & 166 & $21(12.7)$ \\
As stable* & 401 & $134(33.4)$ & 160 & $43(26.9)$ & 166 & $55(33.1)$ \\
As slightly worsened* & 401 & $63(15.7)$ & 160 & $19(11.9)$ & 166 & $22(13.3)$ \\
As much worsened* & 401 & $10(2.5)$ & 160 & $2(1.3)$ & 166 & $4(2.4)$ \\
& & & & & &
\end{tabular}

* Assessed at second study visit.

Table 5. Assessment of drug therapies, side effects of medications, therapeutic compliance, and school problems in the questionnaires completed by the parents at study entry and in the first questionnaire completed simultaneously by parents and children. Values are $\mathrm{n}(\%)$.

\begin{tabular}{|c|c|c|c|c|c|c|}
\hline \multirow[b]{3}{*}{ Feature } & \multicolumn{3}{|c|}{$\begin{array}{c}\text { Parent-Only } \\
\text { Questionnaires, } \mathrm{n}=618\end{array}$} & \multicolumn{3}{|c|}{$\begin{array}{c}\text { Paired Child-Parent } \\
\text { Questionnaires, } \mathrm{n}=332\end{array}$} \\
\hline & & & & Children & & Parents \\
\hline & $\mathrm{N}$ & & $\mathrm{N}$ & & $\mathrm{N}$ & \\
\hline Patients receiving medications & 618 & $369(59.7)$ & 332 & $199(59.9)$ & 332 & $198(59.6)$ \\
\hline Nonsteroidal antiinflammatory drugs & 618 & $188(30.4)$ & 332 & $73(22.0)$ & 332 & $79(23.8)$ \\
\hline Systemic corticosteroids & 618 & $39(6.3)$ & 332 & $18(2.9)$ & 332 & $16(2.6)$ \\
\hline Methotrexate & 618 & $204(33.0)$ & 332 & $99(29.8)$ & 332 & $111(33.4)$ \\
\hline Cyclosporine & 618 & $15(2.4)$ & 332 & $7(2.1)$ & 332 & $6(1.8)$ \\
\hline Sulfasalazine & 618 & $7(1.1)$ & 332 & $4(1.2)$ & 332 & $5(1.5)$ \\
\hline Etanercept & 618 & $51(8.3)$ & 332 & $46(13.9)$ & 332 & $46(13.9)$ \\
\hline Anakinra & 618 & $12(1.9)$ & 332 & $8(1.3)$ & 332 & $9(1.5)$ \\
\hline Other biologics & 618 & $7(1.1)$ & 332 & $3(0.9)$ & 332 & $3(0.9)$ \\
\hline Patients with side effects & 618 & $170(27.5)$ & 332 & $99(29.8)$ & 332 & $94(28.3)$ \\
\hline Nausea & 618 & $56(9.1)$ & 332 & $41(12.3)$ & 332 & $42(12.7)$ \\
\hline Gastric discomfort & 618 & $47(7.6)$ & 332 & $25(7.5)$ & 332 & $26(7.8)$ \\
\hline Mood changes & 618 & $40(6.5)$ & 332 & $14(4.2)$ & 332 & $17(5.1)$ \\
\hline Headache & 618 & $30(4.9)$ & 332 & $28(8.4)$ & 332 & $26(7.8)$ \\
\hline Weight gain & 618 & $24(3.9)$ & 332 & $16(4.8)$ & 332 & $16(4.8)$ \\
\hline Hypertrichosis & 618 & $21(3.4)$ & 332 & $6(1.8)^{*}$ & 332 & $15(4.5)^{*}$ \\
\hline Vomiting & 618 & $19(3.1)$ & 332 & $9(2.7)$ & 332 & $6(1.8)$ \\
\hline Pain in the injection site & 618 & $9(1.5)$ & 332 & $6(1.8)$ & 332 & $6(1.8)$ \\
\hline $\begin{array}{l}\text { Subjects reporting problems with } \\
\text { therapeutic compliance }\end{array}$ & 618 & $24(3.9)$ & 332 & $13(3.9)$ & 332 & $12(3.6)$ \\
\hline Subjects reporting problems at school ${ }^{\dagger}$ & 521 & $159(30.5)$ & 317 & $83(26.1)$ & 317 & $88(27.7)$ \\
\hline Subjects satisfied with illness outcome & 584 & $385(65.9)$ & 325 & $227(69.8)$ & 323 & $241(74.6)$ \\
\hline
\end{tabular}

$* \mathrm{p}<0.05{ }^{\dagger}$ Among patients attending school. 
Table 6. Parent-child Spearman correlations of quantitative measures included in the JAMAR, by child's age.

\begin{tabular}{lccc}
\hline & \multicolumn{3}{c}{ Child's Age } \\
Measure & $\begin{array}{c}<10 \mathrm{yrs}, \\
\mathrm{n}=92\end{array}$ & $\begin{array}{c}10-15 \mathrm{yrs}, \\
\mathrm{n}=159\end{array}$ & $>15 \mathrm{yrs}$, \\
& & & $\mathrm{n}=81$ \\
\hline JAFS total score & 0.67 & 0.83 & 0.82 \\
PRQL total score & 0.75 & 0.75 & 0.67 \\
PRQL PhH score & 0.76 & 0.77 & 0.74 \\
PRQL PsH score & 0.68 & 0.57 & 0.49 \\
VAS well-being & 0.71 & 0.80 & 0.79 \\
VAS pain & 0.79 & 0.87 & 0.84 \\
VAS disease activity & 0.77 & 0.79 & 0.84 \\
\hline
\end{tabular}

JAMAR: Juvenile Arthritis Multidimensional Assessment Report; JAFS: Juvenile Arthritis Functionality Scale; PRQL: Pediatric Rheumatology Quality of Life scale; PhH: physical health; PsH: psychosocial health; VAS: visual analog scale.

\section{DISCUSSION}

We have described the development of a new multidimensional questionnaire that combines the traditional patient-reported outcomes used in the clinical evaluation of children with JIA, such as assessment of overall well-being, pain, functional status, and HRQOL, with other PRO not addressed by conventional instruments, including measurement of morning stiffness and overall level of disease activity, rating of disease status and course, proxy- or self-assessment of joint involvement and extraarticular symptoms, description of side effects of medications, and assessment of therapeutic compliance and satisfaction with outcome. The JAMAR enables the registration of all these data in a single instrument in a standardized manner. The questionnaire is not intended to serve as a "measure" for research or clinical trials. Rather, it has been specifically designed for regular administration in daily clinical practice. However, some components that yield quantitative scores (i.e., the physical function and HRQOL tools and the VAS scales) or that are categorical (i.e., assessment of disease state and course, and morning stiffness) can be used in clinical research.

The JAMAR is proposed for use as both a proxy-report and a patient self-report, with the suggested age range of 7-18 years for use as a self-report. The questionnaire format has been found to be very user-friendly, easy to understand, and readily answered by parents and patients. It is quick, taking less than 15 minutes to complete, and can be scanned by a health professional for a clinical overview in a few seconds. Scoring of components can be accomplished in less than 5 minutes and the data are immediately amenable to entry onto a patient's chart.

Although a number of instruments are available for

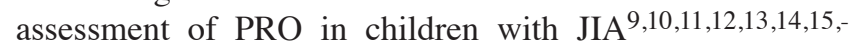
$16,17,18,19,20$, most of these measures are not routinely administered in most pediatric rheumatology centers. This is partly explained by the concern that questionnaires may interfere with office routine and time management, with consequent increased costs and time. However, it has been suggested that data from a brief questionnaire designed for standard care can provide an important saving of time (after a brief "learning curve," as required with any new activity $)^{21}$. With administration of such a questionnaire, information concerning functional status, HRQOL, global status, pain, morning stiffness, burden of arthritis, disease course from previous visit, and medication side effects are already known by the physician at the start of the visit, rather than when acquiring basic data from the parent. This facilitates focus on matters that require attention, leading to more efficient and effective clinical care.

Over the last 2 years, a simple system has been implemented effectively at the study centers that can assure completion of the JAMAR by almost every parent/patient. In the case of inpatients, the questionnaire is completed the day of

Table 7. Values of quantitative and categorical measures included in the JAMAR, by severity of joint disease. Except where indicated, values are median (interquartile range).

\begin{tabular}{|c|c|c|c|c|c|c|}
\hline \multirow[b]{2}{*}{ Measure } & \multicolumn{3}{|c|}{ Active Joint Count* } & \multicolumn{3}{|c|}{ Restricted Joint Count* } \\
\hline & $\begin{array}{c}0 \\
\mathrm{n}=210\end{array}$ & $\begin{array}{c}1-4 \\
\mathrm{n}=215\end{array}$ & $\begin{array}{c}\geq 5 \\
\mathrm{n}=61\end{array}$ & $\begin{array}{c}0 \\
\mathrm{n}=240\end{array}$ & $\begin{array}{c}1-4 \\
\mathrm{n}=184\end{array}$ & $\begin{array}{c}\geq 5 \\
\mathrm{n}=62\end{array}$ \\
\hline PRQL total score & $1(0 ; 4)$ & $4(2 ; 8)$ & $7(2 ; 12)$ & $2(0 ; 4)$ & $5(2 ; 8.5)$ & $5(2 ; 9)$ \\
\hline PRQL PhH score & $0(0 ; 2)$ & $2(1 ; 5)$ & $4(2 ; 8)$ & $1(0 ; 2)$ & $3(1 ; 5)$ & $3(1 ; 7)$ \\
\hline PRQL PsH score & $0(0 ; 2)$ & $2(0 ; 3)$ & $3(1 ; 5)$ & $1(0 ; 2)$ & $2(0.5 ; 4)$ & $2(0 ; 4)$ \\
\hline VAS disease activity & $0(0 ; 1)$ & $3(0.5 ; 5.25)$ & $5(2.5 ; 7)$ & $0(0 ; 1.5)$ & $3(0.5 ; 6)$ & $4.5(1 ; 5.75)$ \\
\hline No. patients with morning stiffness (\%) & $32(15.5)$ & $104(49.3)$ & $44(72.1)$ & $49(20.9)$ & $92(50.5)$ & $39(62.9)$ \\
\hline \multicolumn{7}{|l|}{ Assessment of disease status, $\mathrm{n}(\%)$} \\
\hline Patients with remission & $160(77.7)$ & $48(22.6)$ & $7(11.9)$ & $159(67.7)$ & $43(23.8)$ & $13(21.3)$ \\
\hline Patients with continued activity & $24(11.7)$ & $90(42.5)$ & $34(57.6)$ & $37(15.7)$ & $78(43.1)$ & $33(54.1)$ \\
\hline Patients with disease flare & $22(10.7)$ & 74 (34.9) & $18(30.5)$ & 39 (16.6) & $60(33.1)$ & 15 (24.6) \\
\hline
\end{tabular}

$* \mathrm{p}<0.0001$ for all 3-group comparisons. JAMAR: Juvenile Arthritis Multidimensional Assessment Report; JAFS: Juvenile Arthritis Functionality Scale; PRQL: Pediatric Rheumatology Quality of Life scale; PhH: physical health; PsH: psychosocial health; VAS: visual analog scale.

Personal non-commercial use only. The Journal of Rheumatology Copyright $\subset$ 2011. All rights reserved. 
hospital admission in the ward room, whereas in outpatients the questionnaire is completed in the waiting area before the patient is called into an examining room. To enhance interest of parents and patients in the questionnaire, it is presented by staff in a cheerful and positive manner as an important component of medical care. Completion of the questionnaire helps the parent and the patient to focus on information needed for care and enhances their capacity to describe concerns in the limited time allotted for a clinical encounter.

The JAMAR has been designed specifically for busy clinical settings, with particular attention to feasibility and acceptability in daily care. To avoid making it too lengthy and complex, we selected 2 simple and short measures for assessment of the central domains of physical function and HRQOL. The VAS for pain, well-being, and disease activity are presented as 21-numbered circles, rather than in the traditional $10-\mathrm{cm}$ horizontal line format, to facilitate scoring without a ruler. Use of the simpler 21-circle horizontal line VAS has been found to increase the precision of parent/patient ratings, particularly regarding definition of remission ${ }^{25}$. The JAMAR is the first questionnaire to include a proxy- or self-report assessment of articular symptoms.

Regular use of the JAMAR enables keeping a flow sheet of patient's course over time. A flow sheet may facilitate the recognition of possible changes in functional capacity, pain, fatigue, and psychological status from previous visits ${ }^{22}$. This method of handling clinical data appears very useful in the management of a chronic disease such as JIA as it allows the clinician to record serial parent/patient data, together with joint examination findings, laboratory tests, medication regimen, and other information.

Our work should be viewed in the light of some potential limitations. The JAMAR may not provide sufficient detail regarding PRO of sleep disturbance, fatigue, coping, and family life. Further development of the JAMAR requires continuing research, with introduction of possible modifications based on clinical experience. We recognize that the way parents and children are asked about compliance may not be sufficiently accurate and that appropriate assessment of therapeutic compliance or adherence requires the use of a more specific and detailed instrument ${ }^{31}$. Children and parents were told to complete the questionnaire independently. However, since we could not watch all parent-child pairs during completion of questionnaires, we cannot exclude that some parents assisted their children. Although there were very few missing data in child-reported questionnaires, we cannot exclude that some questions/items in the JAMAR may be hard for accurate understanding by younger children. Since juvenile spondyloarthropathy is a particular form of JIA, some measures included in JAMAR may perform differently. Because children with enthesitis-related arthritis were underrepresented in the study sample (2.1\%), our findings may be of limited value for this JIA subset.
Although we present the English translation of the questionnaires, the instrument was tested in Italian parents and patients. It is possible that children and their parents elsewhere might respond differently to the JAMAR questions due to cultural and language differences. Thus, our results should be confirmed at other sites and in different cultural environments before the new questionnaire is widely adopted.

Development of the JAMAR provides a promising approach to quantitative measurement in standard pediatric rheumatology care. Availability of this new instrument may foster regular use of parent/patient questionnaires in routine practice and contribute to improved quality of care of children with JIA.

\section{REFERENCES}

1. Duffy CM. Measurement of health status, functional status, and quality of life in children with juvenile idiopathic arthritis: clinical science for the pediatrician. Pediatr Clin North Am 2005;52:359-72.

2. Brunner HI, Giannini EH. Health-related quality of life in children with rheumatic diseases. Curr Opin Rheumatol 2003;15:602-12.

3. Feldman BM, Grundland B, McCullough L, Wright V. Distinction of quality of life, health related quality of life, and health status in children referred for rheumatologic care. J Rheumatol 2000;27:226-33.

4. Brunner HI, Ravelli A. Developing outcome measures for paediatric rheumatic diseases. Best Pract Res Clin Rheumatol 2009;23:609-24.

5. Oliveira S, Ravelli A, Pistorio A, Castell E, Malattia C, Prieur AM, et al. Proxy-reported health-related quality of life of patients with juvenile idiopathic arthritis: the Pediatric Rheumatology International Trials Organization Multinational Quality of Life Cohort Study. Arthritis Rheum 2007;57:35-43.

6. Garcia-Munitis P, Bandeira M, Pistorio A, Magni-Manzoni S, Ruperto N, Schivo A, et al. Level of agreement between children, parents, and physicians in rating pain intensity in juvenile idiopathic arthritis. Arthritis Rheum 2006;55:177-83.

7. Consolaro A, Vitale R, Pistorio A, Lattanzi B, Ruperto N, Malattia $\mathrm{C}$, et al. Physicians' and parents' ratings of inactive disease are frequently discordant in juvenile idiopathic arthritis. J Rheumatol 2007;34:1773-6.

8. Barton JL, Imboden J, Graf J, Glidden D, Yelin EH, Schillinger D. Patient-physician discordance in assessments of global disease severity in rheumatoid arthritis. Arthritis Care Res 2010;62:857-64.

9. Lovell DJ, Howe S, Shear E, Hartner S, McGirr G, Schulte M, et al. Development of a disability measurement tool for juvenile rheumatoid arthritis. The Juvenile Arthritis Functional Assessment Scale. Arthritis Rheum 1989;32:1390-5.

10. Howe S, Levinson J, Shear E, Hartner S, McGirr G, Schulte M, et al. Development of a disability measurement tool for juvenile rheumatoid arthritis. The Juvenile Arthritis Functional Assessment Report for children and their parents. Arthritis Rheum 1991;34:873-80.

11. Singh G, Athreya BH, Fries JF, Goldsmith DP. Measurement of health status in children with juvenile rheumatoid arthritis. Arthritis Rheum 1994;37:1761-9.

12. Ravelli A, Viola S, Ramenghi B, Di Fuccia G, Ruperto N, Zonta L, et al. Evaluation of response to methotrexate by a functional index in juvenile chronic arthritis. Clin Rheumatol 1995;14:322-6.

13. Wright FV, Longo Kimber J, Law M, Goldsmith CH, Crombie V, Dent P. The Juvenile Arthritis Functional Status Index (JASI): a validation study. J Rheumatol 1996;23:1066-79.

Personal non-commercial use only. The Journal of Rheumatology Copyright (C) 2011. All rights reserved. 
14. Iglesias MJ, Cuttica RJ, Herrera Calvo M, Micelotta M, Brusco MI, Duran P. Design and validation of a new scale to assess the functional ability in children with juvenile idiopathic arthritis (JIA). Clin Exp Rheumatol 2006;24:713-8.

15. Filocamo G, Sztajnbok F, Cespedes-Cruz A, Magni-Manzoni S, Pistorio A, Viola S, et al. Development and validation of a new short and simple measure of physical function for juvenile idiopathic arthritis. Arthritis Rheum 2007;57:913-20.

16. Duffy CM, Arsenault L, Duffy KNW, Paquin JD, Strawczynski H. The Juvenile Arthritis Quality of Life Questionnaire Development of a new responsive index for juvenile rheumatoid arthritis and juvenile spondyloarthritides. J Rheumatol 1997;24:738-46

17. Varni JW, Seid M, Knight TS, Burwinkle T, Brown J, Szer IS. The PedsQL ${ }^{\mathrm{TM}}$ in pediatric rheumatology - Reliability, validity, and responsiveness of the Pediatric Quality of Life Inventory ${ }^{\mathrm{TM}}$ generic core scales and rheumatology module. Arthritis Rheum 2002;46:714-25.

18. Landgraf JM, Abetz L, Ware JE. The CHQ user's manual. Boston: The Health Institute, New England Medical Center; 1996.

19. Moorthy LN, Peterson MG, Baratelli M, Harrison MJ, Onel KB, Chalom EC, et al. Multicenter validation of a new quality of life measure in pediatric lupus. Arthritis Rheum 2007;57:1165-73.

20. Filocamo G, Schiappapietra B, Bertamino M, Pistorio A, Ruperto N, Magni-Manzoni S, et al. A new short and simple health-related quality of life measurement for paediatric rheumatic diseases: Initial validation in juvenile idiopathic arthritis. Rheumatology 2010;49:1272-80. Epub 2010 Mar 24.

21. Pincus T, Sokka T. Complexities in the quantitative assessment of patients with rheumatic diseases in clinical trials and clinical care. Clin Exp Rheumatol 2005;23 Suppl 39:S1-S9.

22. Pincus T, Yazici Y, Bergman M. Development of a multi-dimensional health assessment questionnaire (MDHAQ) for the infrastructure of standard clinical care. Clin Exp Rheumatol 2005;23 Suppl 39:S19-S28.
23. Kalyoncu U, Dougados M, Daurès J-P, Gossec L. Reporting of patient-reported outcomes in recent trials in rheumatoid arthritis: a systematic literature review. Ann Rheum Dis 2009:68:183-90.

24. Gossec L, Dougados M, Rincheval N, Balanescu A, Boumpas DT, Canadelo $\mathrm{S}$, et al. Elaboration of the preliminary Rheumatoid Arthritis Impact of Disease (RAID) score: a EULAR initiative. Ann Rheum Dis 2009;68:1680-5.

25. Filocamo G, Davì S, Pistorio A, Bertamino M, Ruperto N, Lattanzi B, et al. Evaluation of 21-numbered circle and 10-centimeter horizontal line visual analog scales for physician's and parent's subjective ratings in juvenile idiopathic arthritis. J Rheumatol 2010;37:1534-41.

26. Palmisani E, Solari N, Magni-Manzoni S, Pistorio A, Labò E, Panigada $\mathrm{S}$, et al. Relationship between juvenile idiopathic arthritis severity measures in early versus late disease. Arthritis Rheum 2006;55:843-49.

27. Filocamo G, Pistorio A, Bertamino M, Consolaro A, Ferrari C, Lannin S, et al. Are children with juvenile idiopathic arthritis and their parents reliable reporters of joint involvement? Ann Rheum Dis 2009;68 Suppl 3:761.

28. Filocamo G, Schiappapietra B, Palmisani E, Solari N, Pederzoli S, Magni-Manzoni S, et al. What is the maximum level of symptoms that children with juvenile idiopathic arthritis (JIA) and their parents consider acceptable? Ann Rheum Dis 2009;68 Suppl 3:761.

29. Petty RE, Southwood TR, Manners P, Baum J, Glass DN, Goldenberg J, et al. International League of Associations for Rheumatology classification of juvenile idiopathic arthritis: 2nd revision, Edmonton 2001. J Rheumatol 2004;31:390-2.

30. Ravelli A, Viola S, Ruperto N, Corsi B, Ballardini G, Martini A, et al. Correlation between conventional disease activity measures in juvenile chronic arthritis. Ann Rheum Dis 1997;56:197-200.

31. April KT, Feldman DE, Platt RW, Duffy CM. Comparison between children with juvenile idiopathic arthritis and their parents concerning perceived treatment adherence. Arthritis Rheum 2006;55:558-63. 
Appendix 1. Juvenile Arthritis Multidimensional Assessment Report (JAMAR): Parent's version.

Patient's name and surname (or initials):

Date:

Parent filling in the questionnaire:

Mother

Father

The aim of this questionnaire is to gather information on the current state of your child's illness. Your answers will help us improve our clinical evaluation. Please read the questions below carefully and choose the answers that best apply to your child. If you have doubts or need any clarification, please ask for our help. There are no right or wrong answers. We simply ask that you answer exactly as you feel.

\section{Evaluation of functional ability}

Please choose the answer that best describes your child's ability to carry out the activities listed below with particular reference to the past four weeks. Please indicate only the difficulties or limitations caused by the illness. If your child has difficulty carrying out any of these activities because he/she is too young and not because of the illness, indicate "Not applicable".

\begin{tabular}{|l|c|c|c|c|c|}
\hline & $\begin{array}{c}\text { With NO } \\
\text { difficulty }\end{array}$ & $\begin{array}{c}\text { With SOME } \\
\text { difficulty }\end{array}$ & $\begin{array}{c}\text { With MUCH } \\
\text { difficulty }\end{array}$ & $\begin{array}{c}\text { UNABLE } \\
\text { to do }\end{array}$ & $\begin{array}{c}\text { Not } \\
\text { applicable }\end{array}$ \\
\hline 1. Run on flat ground for at least 10 metres & $\square$ & $\square$ & $\square$ & $\square$ & $\square$ \\
\hline 2. Walk up 5 steps & $\square$ & $\square$ & $\square$ & $\square$ & $\square$ \\
\hline 3. Jump forward & $\square$ & $\square$ & $\square$ & $\square$ & $\square$ \\
\hline 4. Squat & $\square$ & $\square$ & $\square$ & $\square$ & $\square$ \\
\hline 5. Bend down to pick up an object off the floor & $\square$ & $\square$ & $\square$ & $\square$ & $\square$ \\
\hline $\begin{array}{l}\text { 6. Carry out activities that require the use of } \\
\text { his/her fingers }\end{array}$ & $\square$ & $\square$ & $\square$ & $\square$ & $\square$ \\
\hline 7. Open and close his/her fists & $\square$ & $\square$ & $\square$ & $\square$ & $\square$ \\
\hline 8. Squeeze an object with his/her hands & $\square$ & $\square$ & $\square$ & $\square$ & $\square$ \\
\hline 9. Open a door by lowering the handle & $\square$ & $\square$ & $\square$ & $\square$ & $\square$ \\
\hline $\begin{array}{l}\text { 10. Open and close a tap or open a previously } \\
\text { opened jar }\end{array}$ & $\square$ & $\square$ & $\square$ & $\square$ & $\square$ \\
\hline 11. Stretch out his/her arms & $\square$ & $\square$ & $\square$ & $\square$ & $\square$ \\
\hline 12. Put his/her hands behind his/her neck & $\square$ & $\square$ & $\square$ & $\square$ & $\square$ \\
\hline $\begin{array}{l}\text { 13. Turn his/her head and look over his/her } \\
\text { shoulders }\end{array}$ & $\square$ & $\square$ & $\square$ & $\square$ & $\square$ \\
\hline $\begin{array}{l}\text { 14. Bend his/her head back and look at the } \\
\text { ceiling }\end{array}$ & $\square$ & $\square$ & $\square$ & $\square$ & $\square$ \\
\hline 15. Bite into a sandwich or an apple & $\square$ & $\square$ & $\square$ & $\square$ & $\square$ \\
\hline
\end{tabular}

2. How much pain has your child had because of the illness over the past week? (choose the most accurate score)

NO

PAIN

EXTREME

$\widehat{\oplus \Theta}$

$\begin{array}{lllllllllllllllllllll}0 & 0.5 & 1 & 1.5 & 2 & 2.5 & 3 & 3.5 & 4 & 4.5 & 5 & 5.5 & 6 & 6.5 & 7 & 7.5 & 8 & 8.5 & 9 & 9.5 & 10\end{array}$

PAIN

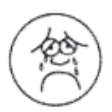


3. Please indicate if today your child is feeling pain or has swelling in any of the joints listed below

\begin{tabular}{|l|c|l|c|}
\hline \multicolumn{1}{|c|}{ LEFT SIDE } & $\begin{array}{c}\text { Presence of } \\
\text { pain or swelling }\end{array}$ & RIGHT SIDE & $\begin{array}{c}\text { Presence of } \\
\text { pain or swelling }\end{array}$ \\
\hline Fingers & $\square$ & Fingers & $\square$ \\
\hline Wrist & $\square$ & Wrist & $\square$ \\
\hline Elbow & $\square$ & Elbow & $\square$ \\
\hline Shoulder & $\square$ & Shoulder & $\square$ \\
\hline Hip & $\square$ & Hip & $\square$ \\
\hline Knee & $\square$ & Knee & $\square$ \\
\hline Ankle & $\square$ & Ankle & $\square$ \\
\hline Toes & $\square$ & Toes & \\
\hline \multicolumn{2}{|l|}{} \\
My child has no joints with pain or swelling & $\square$ & \\
\hline
\end{tabular}

4. Has your child had joint stiffness upon waking up over the past week? $\quad$\begin{tabular}{rl|l|l|}
\cline { 2 - 3 } & Yes \\
\cline { 2 - 3 }
\end{tabular}

If you answered "yes", how long does it last?

\begin{tabular}{|c|c|c|c|c|}
\hline $\begin{array}{c}\text { Less than } \\
15 \text { minutes } \\
\square\end{array}$ & 15 to 30 minutes & $\begin{array}{c}30 \text { minutes } \\
\text { to } 1 \text { hour }\end{array}$ & 1 to 2 hours & $\begin{array}{c}\text { More than } \\
2 \text { hours } \\
\end{array}$ \\
\hline
\end{tabular}

5. Please indicate if your child has had either or both of the symptoms listed below over the past week

\begin{tabular}{|l|c|c|}
\hline Fever $>38^{\circ} \mathrm{C}$ (if due to arthritis) & Yes $\square$ & No $\square$ \\
\hline Skin rash (if due to arthritis) & Yes $\square$ & No $\square$ \\
\hline
\end{tabular}

6. Considering all the symptoms, such as pain, joint swelling, morning stiffness, fever (if due to arthritis), and skin rash (if due to arthritis), please evaluate the level of activity of your child's illness at the moment (choose the most accurate score)

NO

MAXIMUM

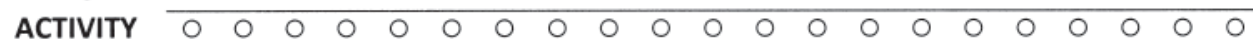

ACTIVITY

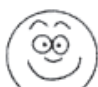

$\begin{array}{lllllllllllllllllllll}0 & 0.5 & 1 & 1.5 & 2 & 2.5 & 3 & 3.5 & 4 & 4.5 & 5 & 5.5 & 6 & 6.5 & 7 & 7.5 & 8 & 8.5 & 9 & 9.5 & 10\end{array}$

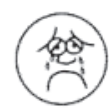

7. How would you evaluate the current state of your child's illness?

\begin{tabular}{|c|c|c|}
\hline $\begin{array}{c}\text { Complete absence of symptoms } \\
\text { (remission) }\end{array}$ & $\begin{array}{c}\text { Continuing presence of symptoms } \\
\text { (persistent activity) }\end{array}$ & $\begin{array}{c}\text { Recurrence of symptoms after a } \\
\text { period of complete well-being } \\
\text { (relapse) }\end{array}$ \\
$\square$ & $\square$ & $\square$ \\
\hline
\end{tabular}

8. Compared to his/her last visit, how would you evaluate the course of your child's illness?

\begin{tabular}{|c|c|c|c|c|}
\hline Much improved & Slightly improved & Stable/unchanged & Slightly worsened & Much worsened \\
$\square$ & $\square$ & $\square$ & $\square$ & $\square$ \\
\hline
\end{tabular}


If you answered "no", please go directly to question 13

If "yes", please also answer questions 10, 11, and 12

10. Which medication is your child currently taking?

\begin{tabular}{|c|c|c|c|c|c|c|c|}
\hline NSAIDs (e.g. & & & $\square$ & \multicolumn{4}{|c|}{ Please specify } \\
\hline Steroids (e.g. & & & \begin{tabular}{l|l}
$\square$ \\
\end{tabular} & \multicolumn{4}{|c|}{ Please specify } \\
\hline Methotrexate (e.g. & ) & $\square$ & Oral $\square$ & \multicolumn{2}{|c|}{ Subcutaneous $\square$} & Intramuscular & $\square$ \\
\hline Salazopyrin (e.g. & ) & $\square$ & \multicolumn{2}{|c|}{ Cyclosporine (e.g. } & & _) & $\square$ \\
\hline Etanercept (Enbrel) & $\square$ & Infliximab ( & (Remicade) & $\square$ & \multicolumn{2}{|c|}{ Adalimumab (Humira) } & $\square$ \\
\hline Golimumab (Simponi) & $\square$ & Certolizuma & ab (Cimzia) & $\square$ & & $\square$ \\
\hline Anakinra (Kineret) & $\square$ & Canakinum & ab (Ilaris) & $\square$ & \multicolumn{2}{|c|}{ Abatacept (Orencia) } & $\square$ \\
\hline Tocilizumab (Actemra) & $\square$ & \multicolumn{3}{|c|}{ Other (please specify } & & ) & $\square$ \\
\hline Other (please specify & & 1 & \begin{tabular}{l|l}
$\square$ & Oth \\
\end{tabular} & her (please sp & ecify & _) & $\square$ \\
\hline
\end{tabular}

11. Since your child's last visit, has he/she had any disturbances which may be caused by the medication he/she is taking? If you answered "yes", please specify which in the table below

\begin{tabular}{|ll|lr|}
\hline Fever & & Pain or burning feeling in the stomach & \\
\hline Headache & $\square$ & Nausea & $\square$ \\
\hline Skin rash & $\square$ & Vomiting & $\square$ \\
\hline Mouth sores & $\square$ & Constipation & $\square$ \\
\hline Swollen/bleeding gums & $\square$ & Diarrhoea & $\square$ \\
\hline Increased body hair & $\square$ & Black or bloody stools & $\square$ \\
\hline Weight gain & $\square$ & Blood in the urine & $\square$ \\
\hline Weight loss & $\square$ & $\begin{array}{l}\text { Swelling, bruising, pain, redness, etc., at the injection } \\
\text { site }\end{array}$ & $\square$ \\
\hline $\begin{array}{l}\text { Mood swings (excitement, depression, } \\
\text { anxiety) }\end{array}$ & $\square$ & Other (please describe)__ & $\square$ \\
\hline Sleep disturbances & $\square$ & Other (please describe) & $\square$ \\
\hline
\end{tabular}

12. Does your child take his/her medication regularly (as prescribed by the doctor) at home? If "no", why not?

\begin{tabular}{|lr|ll|}
\hline He/she refuses to & $\square$ & Too many administrations during the day & $\square$ \\
\hline $\begin{array}{l}\text { Organisational difficulty (for example, } \\
\text { problems taking medication at school) }\end{array}$ & $\square$ & Fear of side effects & $\square$ \\
\hline The child takes too much medication & $\square$ & Other (please specify) & $\square$ \\
\hline
\end{tabular}

Which medication is most difficult to give on a regular basis?

\section{Does your child attend school? $\quad$ Yes $\quad \square$ No $\quad \square$}

If you answered "yes", what school-related problems does the illness cause?

\begin{tabular}{|lr|ll|}
\hline None & $\square$ & Difficulty in his/her relationships with teachers & $\square$ \\
\hline Numerous absences & $\square$ & Decrease in performance & $\square$ \\
\hline Difficulty in remaining seated for a long time & $\square$ & Other (please specify) & \\
& & & $\square$ \\
\hline
\end{tabular}




\section{Evaluation of Quality of Life}

Please choose the answer that best describes your child's overall health.

If a question is not applicable because your child is too young, choose "Not applicable".

Considering the past four weeks, we would like to know if your child:

\begin{tabular}{|l|c|c|c|c|c|}
\hline $\begin{array}{l}\text { 1. Has had any difficulty taking care of him/herself, for } \\
\text { example eating, getting dressed, or washing }\end{array}$ & $\square$ & $\square$ & $\square$ & $\square$ & Ever \\
\hline $\begin{array}{l}\text { 2. Has had any difficulty taking a 15 minute walk or } \\
\text { walking up a flight of stairs }\end{array}$ & $\square$ & $\square$ & $\square$ & $\square$ & $\begin{array}{c}\text { Not } \\
\text { applicable }\end{array}$ \\
\hline $\begin{array}{l}\text { 3. Has had any difficulty carrying out activities that } \\
\text { require a lot of energy such as running, playing } \\
\text { football, dancing etc. }\end{array}$ & $\square$ & $\square$ & $\square$ & $\square$ & $\square$ \\
\hline $\begin{array}{l}\text { 4. Has had any difficulty doing at-school activities or } \\
\text { playing with friends }\end{array}$ & $\square$ & $\square$ & $\square$ & $\square$ & $\square$ \\
\hline 5. Has had any pain & $\square$ & $\square$ & $\square$ & $\square$ & $\square$ \\
\hline 6. Has appeared sad or depressed & $\square$ & $\square$ & $\square$ & $\square$ & $\square$ \\
\hline 7. Has appeared nervous or anxious & $\square$ & $\square$ & $\square$ & $\square$ & $\square$ \\
\hline 8. Has had any trouble getting along with other children & $\square$ & $\square$ & $\square$ & $\square$ & $\square$ \\
\hline $\begin{array}{l}\text { 9. Has had any difficulty concentrating or paying } \\
\text { attention }\end{array}$ & $\square$ & $\square$ & $\square$ & $\square$ & $\square$ \\
\hline $\begin{array}{l}\text { 10. Has appeared to be dissatisfied with his/her physical } \\
\text { appearance or abilities }\end{array}$ & $\square$ & $\square$ & $\square$ & $\square$ & $\square$ \\
\hline
\end{tabular}

15. Considering all the ways the illness affects your child, please evaluate how he/she feels at the moment (choose the most accurate score)

VERY

WELL

$0 \begin{array}{lllllllllllllllllllll}0 & 0 & 0 & 0 & 0 & 0 & 0 & 0 & 0 & 0 & 0 & 0 & 0 & 0 & 0 & 0 & 0 & 0 & 0 & 0 & 0\end{array}$

16. Considering all the ways the illness affects your child, would you be satisfied if his/her condition remained stable/unchanged for the next few months?

\begin{tabular}{|l|l|}
\hline Yes $\square$ & No $\square$ \\
\hline
\end{tabular}

Thank you very much for having taken the time to fill in this questionnaire. The information you have provided will be very useful for following the changes in the course of your child's illness in the best possible way. The information in this questionnaire and in the questionnaire filled in by your child (if applicable) will be kept strictly confidential; and will be used only for clinical or research activities. All data will be handled anonymously. Please indicate if you authorise or do not authorise the use for scientific purposes of the information in this questionnaire and in the questionnaire filled in by your child (if applicable).

\section{I authorise}

I do not authorise

Parent's name and surname or initials (please print)

Signature: 
Appendix 2. Juvenile Arthritis Multidimensional Assessment Report (JAMAR). Child's version.

Patient's name and surname (or initials):

Date:

The aim of this questionnaire is to gather information on the current state of your illness. Your answers will help us improve our clinical evaluation. Please read the questions below carefully and choose the answers that best apply to you. If you have doubts or need any clarification, please ask for our help. There are no right or wrong answers. We simply ask that you answer exactly as you feel.

\section{Evaluation of functional ability}

Please choose the answer that best describes your ability to carry out the activities listed below with particular reference to the past four weeks. Please indicate only the difficulties or limitations caused by the illness.

\begin{tabular}{|l|c|c|c|c|}
\hline & $\begin{array}{c}\text { With NO } \\
\text { difficulty }\end{array}$ & $\begin{array}{c}\text { With SOME } \\
\text { difficulty }\end{array}$ & $\begin{array}{c}\text { With MUCH } \\
\text { difficulty }\end{array}$ & $\begin{array}{c}\text { UNABLE } \\
\text { to do }\end{array}$ \\
\hline 1. Run on flat ground for at least 10 metres & $\square$ & $\square$ & $\square$ & $\square$ \\
\hline 2. Walk up 5 steps & $\square$ & $\square$ & $\square$ & $\square$ \\
\hline 3. Jump forward & $\square$ & $\square$ & $\square$ & $\square$ \\
\hline 4. Squat & $\square$ & $\square$ & $\square$ & $\square$ \\
\hline 5. Bend down to pick up an object off the floor & $\square$ & $\square$ & $\square$ & $\square$ \\
\hline $\begin{array}{l}\text { 6. Carry out activities that require the use of your } \\
\text { fingers }\end{array}$ & $\square$ & $\square$ & $\square$ & $\square$ \\
\hline 7. Open and close your fists & $\square$ & $\square$ & $\square$ & $\square$ \\
\hline 8. Squeeze an object with your hands & $\square$ & $\square$ & $\square$ & $\square$ \\
\hline 9. Open a door by lowering the handle & $\square$ & $\square$ & $\square$ & $\square$ \\
\hline $\begin{array}{l}\text { 10. Open and close a tap or open a previously opened } \\
\text { jar }\end{array}$ & $\square$ & $\square$ & $\square$ & $\square$ \\
\hline 11. Stretch out your arms & $\square$ & $\square$ & $\square$ & $\square$ \\
\hline 12. Put your hands behind your neck & $\square$ & $\square$ & $\square$ & $\square$ \\
\hline 13. Turn your head and look over your shoulders & $\square$ & $\square$ & $\square$ & $\square$ \\
\hline 14. Bend your head back and look at the ceiling & $\square$ & $\square$ & $\square$ & $\square$ \\
\hline 15. Bite into a sandwich or an apple & $\square$ & $\square$ & $\square$ & $\square$ \\
\hline
\end{tabular}

\section{How much pain have you had because of the illness over the past week? \\ (choose the most accurate score)}

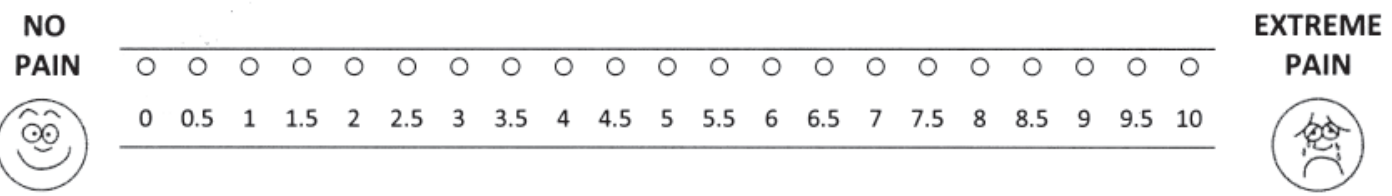


3. Please indicate if today you are feeling pain or have swelling in any of the joints listed below

\begin{tabular}{|l|c|l|c|}
\hline \multicolumn{1}{|c|}{ LEFT SIDE } & $\begin{array}{c}\text { Presence of } \\
\text { pain or swelling }\end{array}$ & RIGHT SIDE & $\begin{array}{c}\text { Presence of } \\
\text { pain or swelling }\end{array}$ \\
\hline Fingers & $\square$ & Fingers & $\square$ \\
\hline Wrist & $\square$ & Wrist & $\square$ \\
\hline Elbow & $\square$ & Elbow & $\square$ \\
\hline Shoulder & $\square$ & Shoulder & $\square$ \\
\hline Hip & $\square$ & Hip & $\square$ \\
\hline Knee & $\square$ & Knee & $\square$ \\
\hline Ankle & $\square$ & Ankle & $\square$ \\
\hline Toes & $\square$ & Toes & \\
\hline
\end{tabular}

4. Have you had joint stiffness upon waking up over the past week? \begin{tabular}{|r|r|r|}
\hline Yes & No
\end{tabular}

If you answered "yes", how long does it last?

\begin{tabular}{|c|c|c|c|c|}
\hline $\begin{array}{c}\text { Less than } \\
15 \text { minutes }\end{array}$ & 15 to 30 minutes & $\begin{array}{c}30 \text { minutes } \\
\text { to } 1 \text { hour }\end{array}$ & 1 to 2 hours & $\begin{array}{c}\text { More than } \\
2 \text { hours }\end{array}$ \\
$\square$ & $\square$ & $\square$ & $\square$ & $\square$ \\
\hline
\end{tabular}

5. Please indicate if you have had either or both of the symptoms listed below over the past week

\begin{tabular}{|l|c|c|}
\hline Fever $>38^{\circ} \mathrm{C}$ (if due to arthritis) & Yes $\square$ & No $\square$ \\
\hline Skin rash (if due to arthritis) & Yes $\square$ & No $\square$ \\
\hline
\end{tabular}

6. Considering all the symptoms, such as pain, joint swelling, morning stiffness, fever (if due to arthritis), and skin rash (if due to arthritis), please evaluate the level of activity of your illness at the moment (choose the most accurate score)

NO

$\begin{array}{cccccccccccccccccccccc}\text { ACTIVITY } & 0 & 0 & 0 & 0 & 0 & 0 & 0 & 0 & 0 & 0 & 0 & 0 & 0 & 0 & 0 & 0 & 0 & 0 & 0 & 0 & 0 \\ (00 & 0 & 0.5 & 1 & 1.5 & 2 & 2.5 & 3 & 3.5 & 4 & 4.5 & 5 & 5.5 & 6 & 6.5 & 7 & 7.5 & 8 & 8.5 & 9 & 9.5 & 10\end{array}$

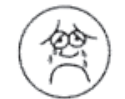

7. How would you evaluate the current state of your illness?

\begin{tabular}{|c|c|c|}
\hline $\begin{array}{c}\text { Complete absence of symptoms } \\
\text { (remission) }\end{array}$ & $\begin{array}{c}\text { Continuing presence of symptoms } \\
\text { (persistent activity) }\end{array}$ & $\begin{array}{c}\text { Recurrence of symptoms after a } \\
\text { period of complete well-being } \\
\text { (relapse) }\end{array}$ \\
$\square$ & $\square$ & $\square$ \\
\hline
\end{tabular}

8. Compared to your last visit, how would you evaluate the course of your illness?

\begin{tabular}{|c|c|c|c|c|}
\hline Much improved & Slightly improved & Stable/unchanged & Slightly worsened & Much worsened \\
$\square$ & $\square$ & $\square$ & $\square$ & $\square$ \\
\hline
\end{tabular}


If you answered "no", please go directly to question 13

If "yes", please also answer questions 10, 11 and, 12

10. Which medication are you currently taking?

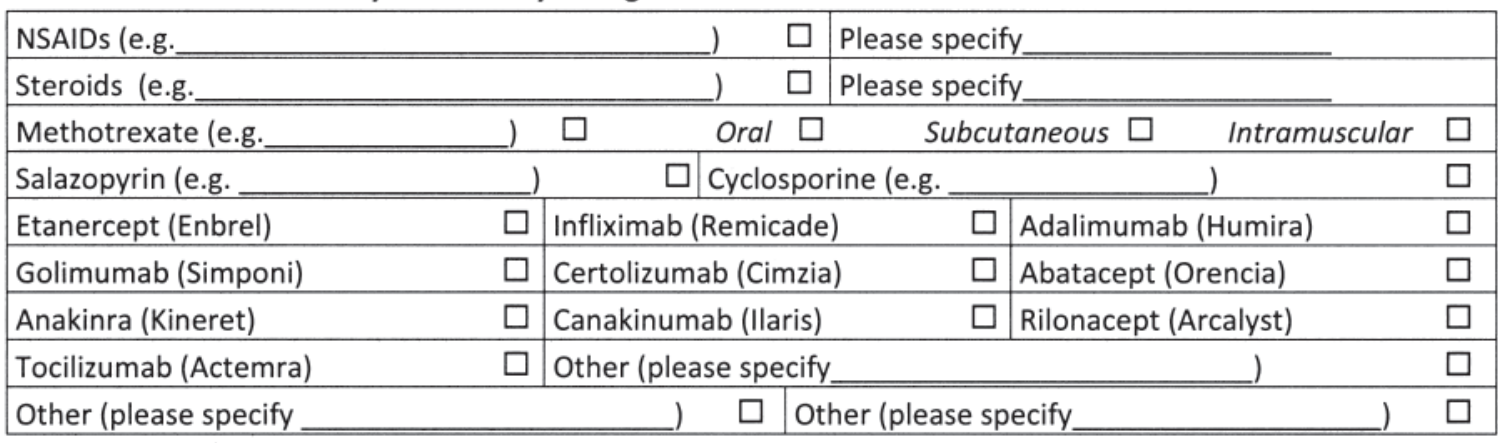

11. Since your last visit, have you had any disturbances which may be caused by the medication you are taking?

If you answered "yes", please specify which in the table below

\begin{tabular}{|ll|lr|}
\hline Fever & & Pain or burning feeling in the stomach & $\square$ \\
\hline Headache & $\square$ & Nausea & $\square$ \\
\hline Skin rash & $\square$ & Vomiting & $\square$ \\
\hline Mouth sores & $\square$ & Constipation & $\square$ \\
\hline Swollen/bleeding gums & $\square$ & Diarrhoea & $\square$ \\
\hline Increased body hair & $\square$ & Black or bloody stools & $\square$ \\
\hline Weight gain & $\square$ & Blood in the urine & $\square$ \\
\hline Weight loss & $\square$ & $\begin{array}{l}\text { Swelling, bruising, pain, redness, etc., at the injection } \\
\text { site }\end{array}$ & $\square$ \\
\hline $\begin{array}{l}\text { Mood swings (excitement, depression, } \\
\text { anxiety) }\end{array}$ & $\square$ & Other (please describe)__ & $\square$ \\
\hline Sleep disturbances & $\square$ & Other (please describe)_ & $\square$ \\
\hline
\end{tabular}

12. Do you take your medication regularly (as prescribed by the doctor) at home?

If "no", why not?

\begin{tabular}{|lr|lc|}
\hline I refuse to & $\square$ & Too many administrations during the day & $\square$ \\
\hline $\begin{array}{l}\text { Organisational difficulty (for example, } \\
\text { problems taking medication at school) }\end{array}$ & $\square$ & Fear of side effects & $\square$ \\
\hline I take too much medication & $\square$ & Other (please specify) & $\square$ \\
\hline
\end{tabular}

Which medication is most difficult to take on a regular basis?

\section{Do you attend school? $\quad$\begin{tabular}{|l|l|}
\hline Yes & No $\quad \square$ \\
\hline
\end{tabular}}

If you answered "yes", what school-related problems does the illness cause?

\begin{tabular}{|lc|ll|}
\hline None & $\square$ & Difficulty in my relationships with teachers & $\square$ \\
\hline Numerous absences & $\square$ & Decrease in performance & $\square$ \\
\hline Difficulty in remaining seated for a long time & $\square$ & Other (please specify) & $\square$ \\
& & & \\
& & \\
\hline
\end{tabular}


14. Evaluation of Quality of Life

Please choose the answer that best describes your overall health.

Considering the past four weeks, we would like to know if you:

\begin{tabular}{|c|c|c|c|c|}
\hline & Never & $\begin{array}{l}\text { Some- } \\
\text { times }\end{array}$ & Often & Every day \\
\hline $\begin{array}{l}\text { 1. Have had any difficulty taking care of yourself, for example eating, } \\
\text { getting dressed, or washing }\end{array}$ & $\square$ & $\square$ & $\square$ & $\square$ \\
\hline $\begin{array}{l}\text { 2. Have had any difficulty taking a } 15 \text { minute walk or walking up a } \\
\text { flight of stairs }\end{array}$ & $\square$ & $\square$ & $\square$ & $\square$ \\
\hline $\begin{array}{l}\text { 3. Have had any difficulty carrying out activities that require a lot of } \\
\text { energy such as running, playing football, dancing etc. }\end{array}$ & $\square$ & $\square$ & $\square$ & $\square$ \\
\hline $\begin{array}{l}\text { 4. Have had any difficulty doing at-school activities or playing with } \\
\text { friends }\end{array}$ & $\square$ & $\square$ & $\square$ & $\square$ \\
\hline 5. Have had any pain & $\square$ & $\square$ & $\square$ & $\square$ \\
\hline 6. Have felt sad or depressed & $\square$ & $\square$ & $\square$ & $\square$ \\
\hline 7. Have felt nervous or anxious & $\square$ & $\square$ & $\square$ & $\square$ \\
\hline 8. Have had any trouble getting along with other children & $\square$ & $\square$ & $\square$ & $\square$ \\
\hline 9. Have had any difficulty concentrating or paying attention & $\square$ & $\square$ & $\square$ & $\square$ \\
\hline 10. Have felt dissatisfied with your physical appearance or abilities & $\square$ & $\square$ & $\square$ & $\square$ \\
\hline
\end{tabular}

15. Considering all the ways the illness affects you, please evaluate how you feel at the moment (choose the most accurate score)

VERY

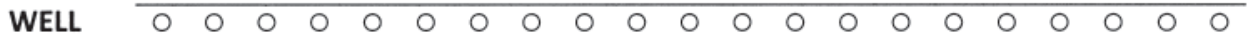

16. Considering all the ways the illness affects you, would you be satisfied if your condition remained stable/unchanged for the next few months?

\begin{tabular}{|l|l|}
\hline Yes $\square$ & No $\square$ \\
\hline
\end{tabular}

Thank you very much for having taken the time to fill in this questionnaire. The information you have provided will be very useful for following the changes in the course of your illness in the best possible way. 